\title{
Morphological characterization and genetic divergence of a cashew population in Floriano, Piauí, Brazil
}

\author{
L.A. Carneiro ${ }^{1}$, L.S. Silva ${ }^{1}$, M.F.C. Gomes ${ }^{2}$, M.F. Santos ${ }^{3}$, \\ S.E.S. Valente ${ }^{4}$, R.L.F. Gomes ${ }^{5}$ and M.F. Costa ${ }^{1}$ \\ ${ }^{1}$ Campus Amílcar Ferreira Sobral, Universidade Federal do Piauí, Floriano, \\ PI, Brasil \\ ${ }^{2}$ Campus Professor Ariston Dias Lima, Universidade Estadual do Piauí, São \\ Raimundo Nonato, PI, Brasil \\ ${ }^{3}$ Campus Senador Helvídio Nunes de Barros, Universidade Federal do Piauí, \\ Picos, PI, Brasil \\ ${ }^{4}$ Departamento de Biologia, Campus Ininga, Universidade Federal do Piauí, \\ Teresina, PI, Brasil \\ ${ }^{5}$ Departamento de Fitotecnia, Campus Ininga, Universidade Federal do Piauí, \\ Teresina, PI, Brasil
}

Corresponding author: M.F. Costa

E-mail: marconescosta@ufpi.edu.br

Genet. Mol. Res. 18 (3): gmr18348

Received May 07, 2018

Accepted July 01, 2019

Published July 04, 2019

DOI http://dx.doi.org/10.4238/gmr18348

ABSTRACT. Anacardium occidentale (cashew) is a tropical tree species that occurs mainly in northeastern Brazil. The species has great socioeconomic importance for rural populations. We investigated the genetic diversity of a natural cashew population in a rural area of Floriano, State of Piauí, Brazil. We quantitatively evaluated 12 natural variables related to the inflorescence, the cashew nut (fruit), and the peduncle (pseudofruit) in 35 trees (numbered sequentially G1-35). The characteristics of the peduncle (pseudofruit) appeared as the variables that most contributed to genetic divergence, while characteristics related to the inflorescence contributed less to the morphological differentiation. Multivariate statistics, employing principal component analysis evidenced that the first three principal components explained $81.72 \%$ of the total variance. Cashews G-3 
and G-8 were identified as the most divergent, with G-3 demonstrating the greatest peduncle lengths and weights.

Key words: Anacardium occidentale; Multivariate analysis; Genetic diversity

\section{INTRODUCTION}

The cashew tree (genus Anacardium) is native to Brazil and demonstrates wide diversity in various biomes in that country; it occurs mainly in Northeast Brazil (Bitu et al., 2015). Taxonomists recognize 11 species in the genus, of which eight are encountered in Brazil (Vieira et al., 2014).

Anacardium species have significant economic importance throughout the world, principally because of two of its natural products: the cashew nut itself (botanically, the fruit) and the pseudofruit (which is actually an expanded and fleshy peduncle) (Schweiggert et al., 2016). Brazil is one of the largest producers of cashew nuts, with 109.68 thousand tons, also standing out in the production of the pseudofruit, with 1,805 thousand tons (FAO, 2016).

Biological compounds such as flavonoids, carotenoids, and vitamins ( $\mathrm{C}$ and $\mathrm{A})$ are also present in the fruit (Souza et al., 2017). In Brazil, the peduncle is consumed fresh, although approximately $10 \%$ of its production is processed into vitamin-rich juices, jellies, alcoholic beverages, and sweets. In addition, cashew extracts have been used as alternative medicines because they have anesthetic and bactericidal properties (Kubo et al., 2011; Kulis et al., 2012; Silva et al., 2013).

It is important to note the importance of plant genetic resources to cashew biodiversity studies - especially those biodiversity components that demonstrate current or potential utility for humans. Genetic resource distributions reflect combinations of both the natural and anthropic processes that transform ecosystems (Govindaraj et al., 2015).

The use of morphological descriptors stands out as one of the main instruments for the characterization and quantification of genetic diversity in cashew trees. This characterization has been carried out through a set of botanical, morphological and agronomic descriptors, which are related mainly to inflorescence, fruit and pseudofruit. In that sense, plant genetic resource conservation is a theme of enormous relevance, and those studies are largely based on analyses of genetic diversity (Thimmappaiah et al., 2009; Cota et al., 2017; Borges et al., 2018).

Biometric characterization consists in evaluating morphological traits of different parts of the plant, such as fruits and seeds (Zuffo et al., 2019). One of the tools that aids the determination of genetic divergence of a species is biometric analysis (Costa et al., 2016; Menegatti et al., 2017; Santos et al., 2018). In this context, biometrics is considered an important tool for identification as a source of information for studies of genetic diversity (Zuffo et al., 2016)

Genetic diversity in evaluations depend on the information available to researchers and can be estimated from phenotypic genetic markers. Research projects designed to quantify and evaluate the magnitude of genetic variability in cashews have been undertaken by researchers such as Santosand\& Santos Júnior (2015) and Pereira et al. (2016). 
The purpose of this study was to characterize the genetic diversity of natural cashew populations by phenotypic markers, to generate information that could subsidize the preservation and conservation of the genetic resources of this important fruit tree.

\section{MATERIAL AND METHODS}

We evaluated 35 adult cashew trees from a natural population, located in the rural zone of Floriano, Piauí State, Brazil (-6 $58^{\prime} 36.4^{\prime \prime} \mathrm{S} x-43^{\circ} 05^{\prime} 26.7^{\prime}$ 'W). The plants were selected according to the availability of flowers, fruits and pseudofruits. Data relative to their morphological characterizations were collected during the reproductive phases (flowering and fruiting). Field expeditions to collect inflorescences, fruits, and pseudofruits were undertaken in August and October/2017. The plants evaluated were identified as G-1 through G-35, based simply on their collection order.

After collection, the materials were transported to the Biology Laboratory of the Campus Amílcar Ferreira Sobral at Floriano, Piaui, for genetic characterization based on multivariate analyses that considered 12 quantitative descriptors of the inflorescences, peduncles, and cashew nuts, as described by the International Board for Plant Genetic Resources -IBPGR (now Biodiversity International; IBPGR, 1986).

The evaluated variables are described in Table 1 .

Table 1. Twelve morphological descriptors selected from the list of cashew descriptors published by IBPGR (now Biodiversity International; IBPGR, 1986).

\begin{tabular}{ll}
\hline Morphological descriptors & Description \\
\hline Inflorescence length & Random measurements during the most intense flowering period. \\
Maximum inflorescence width & The maximum distance between the inflorescence branches \\
Total number of inflorescence ramifications & The numbers of inflorescences in relation to the principal axis \\
Peduncle length & Distance from the apex to the base \\
Peduncle diameter & Measured at the peduncle base \\
peduncle base diameter & Measured at the peduncle base \\
Peduncle apex diameter & Measured at the peduncle apex \\
Peduncle weight & Mean weight of 10 randomly collected peduncles \\
Cashew nut length & Distance from the fixation point to the apex of the cashew nut \\
Cashew nut width & Maximum distance between the shoulders of the cashew nut \\
Cashew nut thickness & Maximum distance between the two sides of the cashew nut \\
Cashew nut weight & The mean weight of 10 randomly collected cashew nuts \\
\hline
\end{tabular}

The measures of inflorescence length and width were made using a millimeter scaled rule; the measures of peduncle and cashew nut lengths, widths, thicknesses and diameters were made using digital calipers (and expressed in millimeters); measurements of mass were made using a precision balance (and expressed in grams).

The physical measurements used 10 specimens of the inflorescences, fruits, and peduncles from each tree examined. Repeatability studies have established that 10 measurements per individual for each characteristic resulted in reliabilities $\geq 90 \%$ (Costa et al., 2016).

The morphological data were submitted to multivariate analyses based on Tocher's methods of grouping optimization, the UPGMA hierarchical method, and Principal Component Analysis (PCA). The analyses were processed using the Genes version 2013.5.1 software. 


\section{RESULTS AND DISCUSSION}

The phenotypic characters examined generally exhibited significant variations, principally those related to the cashew nuts and pseudofruits (peduncles). The phenotypic variance is influenced by components of uncontrolled environments, by the anthropic condition, by the soil, by the climate, by the age of the plants and by the isolation of the genetic species among the individuals (Costa et al., 2015).

The characters inflorescence lengths varied from 6 to $18 \mathrm{~cm}$; the maximum inflorescence width varied from 8 to $25 \mathrm{~cm}$; and the total number of inflorescence ramifications varied from 7 to 12 . Peduncle weights varied from 6.62 to $27.79 \mathrm{~g}$; peduncle lengths varied from 21.63 to $76.79 \mathrm{~mm}$; peduncle diameters varied from 14.42 to $98.48 \mathrm{~mm}$; peduncle base diameters varied from 11.4 to $46.22 \mathrm{~mm}$; peduncle apex diameters varied from 11.72 to $49.13 \mathrm{~mm}$; and cashew nut weights varied between 1.4 and $8.5 \mathrm{~g}$.

A matrix of mean Euclidian distances was used to analyze the genetic diversity of all cashew pairs, yielding a value of 1.32. The analyses of distance estimates indicated genetic dissimilarities, which were corroborated by the maximum and minimum Euclidian distances. The minimum Euclidian distance was 0.32 between cashew trees G-24 and G-25; the maximum estimated Euclidian distance (2.84) was between cashew trees G-3 and G-8.

Divergences were observed in the 12 characters analyzed using the methodology described by Singh (1981), with the variable "peduncle length" contributing most to the observed divergence $(28.85 \%)$, as can be seen in table 2. Zuffo (2018) in his study characterized pseudofruit, fruits and seeds of Anacardium humble and observed large biometric variations, as well as significant and positive correlation between the characteristics analyzed. Jena et al. (2016) evaluated genetic diversity among 12 promising Indian cashew cultivars using morphometrics; a high degree of variation was observed among cultivars with respect to inflorescence length, peduncle weight and nut weight.

Table 2. Relative contributions of the 12 characters measured to the genetic divergence among the cashew trees studied, based on the morphological descriptors and using the methodology described by Singh (1981).

\begin{tabular}{lcc}
\hline Character & S.j & $(\boldsymbol{\%})$ \\
\hline Inflorescence length & 503.11 & 0.18 \\
Maximum inflorescence width & 703.9 & 0.25 \\
Total number of inflorescence ramifications & 115.46 & 0.04 \\
Peduncle length & 80914.37 & 28.85 \\
Peduncle diameter & 28278.54 & 10.08 \\
Peduncle base diameter & 24376.14 & 8.67 \\
Peduncle apex diameter & 30575.36 & 10.9 \\
Peduncle weight & 60124.53 & 21.44 \\
Cashew nut length & 18564.26 & 6.69 \\
Cashew nut width & 8566.06 & 3.05 \\
Cashew nut thickness & 10724.90 & 3.82 \\
Cashew nut weight & 17040.28 & 6.07 \\
\hline S.j: value of the relative & \\
\hline
\end{tabular}

S.j: value of the relative contribution according to SINGH; (\%): value in percentage. 
The Tocher optimization algorithm separated the cashews into four groups considering the 12 characters analyzed, with an intergroup distance of 2.23. Group I comprised $80.01 \%$ of the plants, with an intragroup distance of 1.51. Groups II, III and IV comprised $5.71 \%, 8.57 \%$ and $5.71 \%$ of the cashews evaluated respectively (Table 3 ). Tocher grouping discriminated the individuals genetically, allowing the formation of groups showing internal homogeneity, but heterogeneity between groups.

Table 3. Grouping of the 35 cashew plants, obtained using the Tocher optimization method considering 12 morphological variables.

\begin{tabular}{ll}
\hline Groups & Cashew trees evaluated \\
\hline & G-24, G-25, G-5, G-31, G-32, G-33, G-34, G-15, G-17, G-7, \\
I & G-28, G-18, G-35, G-26, G-12, G-13, G-22, G-6, G-27, G-1, \\
II & G-20, G-4, G-23, G-16, G-19, G-21, G-10, G-29 \\
III & G-2, G-11 \\
IV & G-8, G-9, G-14 \\
\hline
\end{tabular}

One possible explanation for that grouping could be human influences resulting from the introduction of cashew plants (as the samples were collected from rural space the observed phenotypic variations may reflect differences in the local environment/or human selection).

The results of the grouping analysis, based on the 12 morphological descriptors, were revealed through cophenetic correlation coefficients (ccc). According to Rohlf (1970), cophenetic correlation values less than 0.7 indicate the inadequacy of the grouping method. In the present study, the cophenetic correlation value of the dendrogram was 0.95 - indicating the adequacy of that method for grouping the cashews.

By establishing the division point of the dendrogram, it was possible to observe the formation of four groups. The first group was formed by cashew G-3, considered one of the most divergent - and characterized principally by demonstrating elevated peduncle lengths, peduncle diameters, peduncle base diameters, peduncle apex diameters, and peduncle weight values; the second group was formed by G-30, which, like G-3, demonstrated one of the largest values for peduncle length; the third group was composed only of G-8, which demonstrated one of the largest values for cashew nut weight; the other specimens together compose the fourth group, with members G-24 and G-25 demonstrating the smallest genetic distances (Figure 1).

The principal components analysis, based on the 12 morphological descriptors, demonstrated the necessity of only three principal components to explain $81.72 \%$ of the observed variability of the cashew plants. The analyses of the variables with the greatest scores in the constitution of Principal Component 1 (PC1), demonstrated that the characters related to the peduncle, such as its length, apex diameter, and base diameter presented positive combinations in terms of constituting that component. The determination of Principal Component 2 (PC2) revealed associations between variables related to the cashew nut, such as its length and width. 


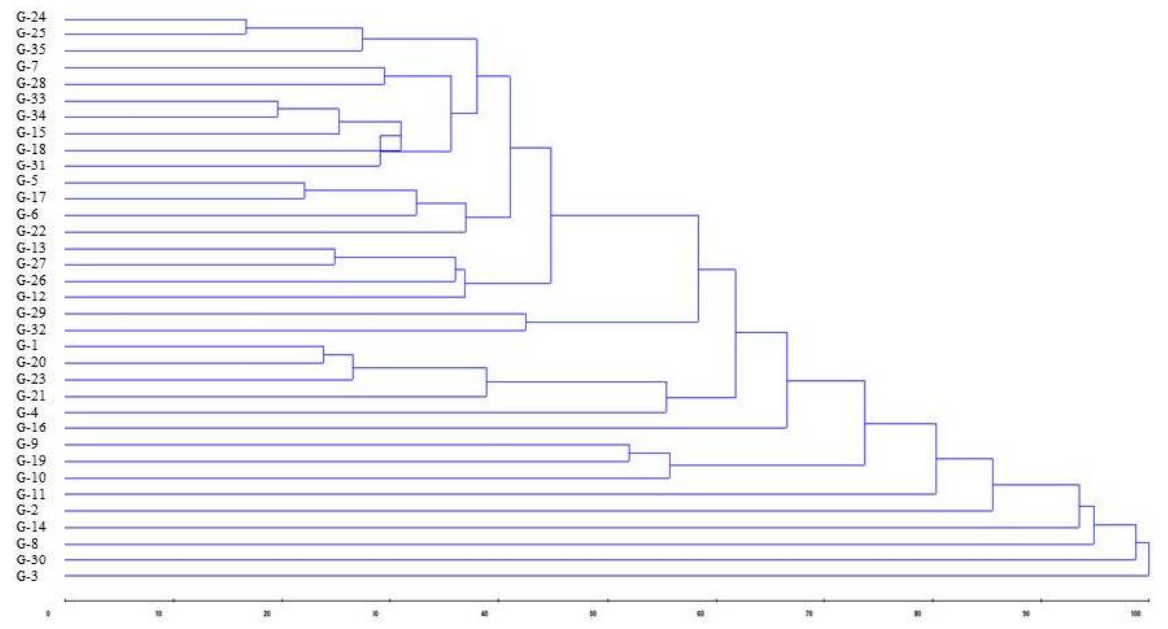

Figure 1. Dendrogram obtained from the analysis of morphological descriptors in a natural population of 35 adult cashew trees (G-1 to G-35) by means of the grouping method UPGMA. Coefficient of correlation coefficient $(r)=0.95$. The plants evaluated were identified as G-1 through G-35, based on their collection order.

The variables related to peduncle lengths and base diameters aligned positively in the constitution of Principal Component 3 (PC3) (Table 4). Most of the plants demonstrated moderate to low values for characters related to the inflorescence, which supported the results obtained using the methodology proposed by Singh (1981), as the variables inflorescence length and maximum width contributed less to the genetic divergence of the plants. Archak et al. (2009) evaluated a total of 91 individuals from 4 cashew populations using morphometric data, so that analysis of diversity showed that the greatest existed in productivity indices (peduncle weight, nut weight and nut yield).

Table 4. Estimates of the eigenvalues associated with the principal components and the percentages and accumulated variances of cashew plant morphological characters.

\begin{tabular}{lccc}
\hline Principal Component & AV & AV(\%) & \% Accumulated \\
\hline PC1 & 293.84 & 50.22 & 59.22 \\
PC2 & 109.85 & 21.65 & 71.87 \\
PC3 & 44.37 & 9.85 & 81.72 \\
PC4 & 20.18 & 7.61 & 89.33 \\
PC5 & 13.54 & 4.82 & 94.15 \\
PC6 & 5.51 & 2.48 & 96.63 \\
PC7 & 4.51 & 2.12 & 98.75 \\
PC8 & 4.33 & 0.61 & 99.36 \\
PC9 & 0.81 & 0.16 & 99.92 \\
PC10 & 0.54 & 0.36 & 99.72 \\
PC11 & 0.070 & 0.213 & 99.93 \\
PC12 & 0.048 & 0.07 & 100 \\
\hline AV: & & &
\end{tabular}

AV: Eigenvalues (AV); AV(\%): Percentage of variance explained; \%: Percentage of variance cumulative ratio

The analyses of the principal components and patterns established by the Tocher and UPGMA grouping methods were in agreement in terms of cashew plant specimen 
discriminations, and demonstrated significant genetic diversity between them. The results of the multivariate analyses allowed the identification of genetic variability among the morphological markers of the cashew trees evaluated here. Cashew G-3 stood out as being one of the most divergent, demonstrating the greatest values related to the peduncle; G- 8 demonstrated the greatest measurements for cashew nut variables.

Biometrics analyses are important tools for examining genetic variability within populations of the same species and the relationship between these variability and environmental factors, as well as offer subsidies for variety identification in breeding programs (Goudel et al., 2013). Both the cashew nut (which constitutes the fruit) and the peduncle (which represents the pseudofruit) have significant economic value. Parameters related to fruits and seeds constitute basic information that indicates the productive and economic potential of the plant as food resource and raw material for industry (Schwartz et al. 2010).

The natural cashew population evaluated presented a great variation in the biometric value of the nut and peduncle, in which they are important characteristics for food and industry. Classical phenotype features are still extremelly useful, moreover, breeding of cashew is mostly based on traditional methods of selection of useful traits which in turn are phenotypes such as nut sinze, nut weight, sex raio, lenght of panicle and yield performace.

\section{CONCLUSIONS}

These results demonstrate the existence of genetic diversity among the morphological characters. The cashew G-3 and G- 8 were found to be the most divergent, with G-3 demonstrating the greatest values for peduncle length and weight. Based on the analysis of the genetic diversity of the natural cashew population by the phenotypic descriptors, we obtained important results that could provide subsidies for the creation of commercial crop areas, since cashew production is an economical alternative for rural communities, as the fruiting period occurs mainly during the dry season, when there are few alternative agricultural production possibilities for small farmers.

\section{REFERENCES}

Archak S, Gaikwad AB, Swamy KRM and Karihaloo JL (2009). Genetic analysis and historical perspective of cashew (Anacardium occidentale L.) introduction into India. Genome. 52 (3): 222-230. https://doi.org/10.1139/G08-119.

Bitu VDCN, Bitu VDCN, Matias EFF, Lima, WP, et al. (2015). Ethnopharmacological study of plants sold for therapeutic purposes in public markets in Northeast Brazil. J. Ethnopharmacol. 172: 265-272. https://doi.org/10.1016/j.jep.2015.06.022.

Borges ANC, Lopes ACA, Brito FB, Vasconcelos LFL, et al. (2018). Genetic diversity in a cajuí (Anacardium spp.) germplasm bank as determined by ISSR markers. Genet. Mol. Res. 17: gmr18212. http://dx.doi.org/ $10.4238 / \mathrm{gmr} 18212$.

Costa FR, Rêgo ER, Rêgo MM, Neder DG, et al. (2015). Análise biométrica de frutos de umbuzeiro do semiárido brasileiro. Biosci. J. 31: 682-690. https://doi.org/10.14393/BJ-v31n3a2015-22844

Costa MF, Lopes ACA, Gomes RLF, Araújo ASFD, et al. (2016). Characterization and genetic divergence of Casearia grandiflora populations in the Cerrado of Piauí state, Brazil. Floram. 23: 387-396. http://dx.doi.org/10.1590/21798087.007115.

Cota LG, Moreira PA, Royo VA, Junior AM, et al. (2017). Structure and genetic diversity of Anacardium humile (Anacardiaceae): a tropical shrub. Genet. Mol. Res. 16: gmr16039778.

Cruz CD (2013). Programa genes: aplicativo computacional em genética e estatística [online]. Viçosa: UFV. Available from: http://www.ufv.br/dbg/ genes/genes.htm.

FAOSTAT (2016). Area harvested and production in principal cashew producing countries. Available at: < http://www.fao.org/faostat/en/\#home. Accessed 30 May 2019. 
Goudel F, Shibata M, Coelho CMM and Miller PRM (2013). Fruit biometry and seed germination of Syagrus romanzoffiana (Cham.) Glassm. Acta Bot. Bras. 27: 147-154. http://dx.doi.org/10.1590/S010233062013000100015

Govindaraj M, Vetriventhan Mv and Srinivasan M (2015). Importance of genetic diversity assessment in crop plants and its recent advances: an overview of its analytical perspectives. Genet. Res. Int. 2015: 431487

IBPGR (1986). Cashew descriptors. International Board for Plant Genetic Resources. Rome.

Jena RC, Samal KC, Pal A, Das BK, et al. (2016). Genetic diversity among some promising Indian local selections and hybrids of cashew nut based on morphometric and molecular markers. Int. J. Fruit Sci. 16(1): 69-93. https://doi.org/10.1080/15538362.2015.104632.

Kubo I, Nitoda T, Tocoli FE and Green IR (2011). Multifunctional cytotoxic agents from Anacardium occidentale. Phytother Res. 25: 38-45. https://doi.org/10.1002/ptr.3109.

Kulis M, MacQueen I, Li Y, Guo R, et al. (2012). Pepsinized cashew proteins are hypoallergenic and immunogenic and provide effective immunotherapy in mice with cashew allergy. J. Allergy Clin. Immunol. 130: 716-723. http://dx.doi.org/doi: 10.1016/j.jaci.2012.05.044

Menegatti RD, Mantovani A, Navroski MC and Graças-Souza A (2017). Genetic divergence among provenances of Mimosa scabrella Benth. based on seed analysis. Rev. Bras. Ciênc Agrárias. 12: 366-371. http://10.5039/agraria.v12i3a5449.

Pereira LD, Costa, ML, Pinto JFN, Assunção HF, et al. (2016). Diversidade genética do florescimento de Anacardium humile A. St. Hill no Sudoeste Goiano. Rev. Bras. Agropecu. Sustent. 6(4): 19-25. http:// dx.doi.org/10.21206/rbas.v6i4.373

Rohlf FJ (1970). Adaptative hierarchical clustering schemes Sys. Biol. 19: 58-82.

Santos RDC and dos Santos Júnior JE (2015). Divergência genética por análise multivariada de caracteres fenotípicos de Anacardium humile (St. Hilaire). Rev. Ceres. 6: 553-560. http://dx.doi.org/10.1590/0034-737X201562060007.

Santos PHRD, Giordani SCO, Soares BC, Silva FHL, et al. (2018). Genetic divergence in populations of Caryocar brasiliense Camb. from the physical characteristics of the fruits. Rev. Árvore. 42: 1-8. http://dx.doi.org/10.1590/1806-90882018000100016.

Schwartz E, Fachinello JC, Barbieri RL and Silva JB (2010). Avaliação de populações de Butia capitata de Santa Vitória do Palmar. Rev. Bras. Frutic. 32: 736-745. http://dx.doi.org/10.1590/S0100-29452010005000089.

Schweiggert RM, Vargas E, Conrad J, Hempel J, et al. (2016). Carotenoids, carotenoid esters, and anthocyanins of yellow-, orange-, and red-peeled cashew apples (Anacardium occidentale L.). Food. Chem. 200: 274-282. https://doi.org/10.1016/j.foodchem.2016.01.038.

Silva RA, Dihl RR, Santos DN, Abreu BRR, et al. (2013). Evaluation of antioxidant and mutagenic activities of honeysweetened cashew apple nectar. Food Chem Toxicol. 62: 61-67. https://doi.org/10.1016/j.fct.2013.08.026.

Singh D (1981). The relative importance of characters affecting genetic divergence. Indian. J. Genet. Pl. Br. 41: 237245.

Souza NC, Oliveira JM, Morrone MDS, Albanus RDO, et al. (2017). Antioxidant and Anti-Inflammatory Properties of Anacardium occidentale Extract. Evid. Based Complement. Alternat. Med. 2017: 2787308 https://doi.org/10.1155/2017/2787308.

Thimmappaiah, Santosh WG, Shobha D and Melwyn GS (2009). Assessment of genetic diversity in cashew germplasm using RAPD and ISSR markers. Sci. Hortic. 120: 411-417. https://doi: 10.1016/j.scienta.2008.11.022.

Vieira M, Mayo SJ and Andrade IM (2014). Geometric morphometrics of leaves of Anacardium microcarpum Ducke and A. occidentale L. (Anacardiaceae) from the coastal region of Piauí, Brazil. Braz. J. Bot. 37: 315-327. https://doi.org/10.1007/s40415-014-0072-3

Zuffo AM, Gesteira GDS, Zuffo-Júnior JMZ, Andrade FR, et al. (2016). Caracterização biométrica de frutos e sementes de mirindiba (Buchenavia tomentosa Eichler) e de inajá (Attalea maripa [Aubl.] Mart.) na região sul do Piauí, Brasil. Rev. Ciênc. Agrár. 39: 331-340. http://dx.doi.org/10.19084/RCA15152.

Zuffo AM (2018). Biometria do hipocarpo, fruto e semente e desenvolvimento das plântulas de Anacardium humile A. St. Hil. (Anacardiaceae). Rev. Ciênc. Agrár. 41: 191-200. http://dx.doi.org/10.19084/RCA18011.

Zuffo AM, Busch A, Steiner F, Alves CZ, et al. (2019). Biometric characteristics of fruits, seeds and plants of Hancornia speciosa Gomes (Apocynaceae). Aust. J. Crop Sci. 13: 622-627. http://dx.doi.org/10.21475/ajcs.19.13.04.p1651. 